\title{
CD5-Positive Blast Cells Greater than 50 Percent
}

National Cancer Institute

\section{Source}

National Cancer Institute. CD5-Positive Blast Cells Greater than 50 Percent. NCI

Thesaurus. Code C148544.

A semi-quantitative microscopic finding indicating that more than $50 \%$ of the immature blood cells in a sample express CD5. 